центр РАН.

VISK = Hakulinen, AUli - Vilkuna,

Maria - Korhonen, Rittta -Koi-

visto, Vesa - Heinonen, Tarja

RiIt ta - Alho, IrJa 2004: Iso suomen

kielioppi. Helsinki: Suomalaisen Kirjal-

lisuuden Seura. Verkkoversio. http:// scripta.kotus.fi/visk (22.2.2020).

Voeltz, F. K. Erhard - Kilian-Hatz, Christa (toim.) 2001: Ideophones.

Amsterdam: Benjamins.

Zaitseva, M. I - Mullonen, M. I. 1972:

Slovarj vepsskogo jazyka. Leningrad:

Nauka.

\title{
Monipuolinen esitys (lähes) tuntemattomasta maanlainsuomennoksesta
}

\author{
Harri Uusitalo: Tausta, tekijä ja kieli. \\ Filologinen tutkimus Aitolahden koodeksin \\ lainsuomennoksesta. Turun yliopiston \\ julkaisuja C471. Turku 2019. 159 s. ja liit- \\ teet 186 s. ISBN 978-951-29-7668-3. Saata- \\ villa verkossa osoitteessa http://urn.fi/ \\ URN:ISBN:978-951-29-7669-0.
}

Harri Uusitalon väitöskirja käsittelee Aitolahden koodeksiin sisältyvää kuningas Kristofferin maanlain suomennosta. Itse koodeksi löydettiin vuonna 1922 navetan vintiltä ja toimitettiin vuonna 1963 Suomalaisen Kirjallisuuden Seuralle. Koodeksiin sisältyy lainsuomennoksen ohessa erilaisia lyhyempiä ruotsinkielisiä tekstejä, muun muassa Lentuluksen kirjeen ruotsinnos. Koodeksin tekstit edustavat eri käsialoja, mutta valtaosa suomen- ja ruotsinkielisestä tekstistä on kirjoitettu samalla käsialalla. Koodeksin maanlainsuomennoksella on selviä yhtäläisyyksiä sekä Martinus Olavin maanlainsuomennoksen (n. 1580) että Ljungo Thomaen maanlainsuomennoksen (1602) kanssa, mutta se ei ole suora kopio kummastakaan niistä. Martinus Olavin ensimmäisestä maanlainsuomennoksesta on säilynyt seitsemän kopiota, mutta Ljungon suomennoksesta vain yksi. Aitolahden lainsuomennos on tähänastisessa tutkimuksessa jäänyt melkein huomiotta, lukuun ottamatta Rapolan (1965) havaintoja. Uusitalon väitös- kirja on näin ollen ensimmäinen laaja tutkimus kyseisestä tekstistä. Tutkimus kohdistuu kielellisten yksityiskohtien asemesta tekstin taustaan kokonaisuudessaan: sen ikään, tekijään sekä suhteeseen muihin teksteihin, esimerkiksi Martinuksen ja Ljungon suomennoksiin.

Väitöskirjan varsinainen tutkimusosa on ytimekäs - 159 sivua lähdeviittaukset mukaan lukien. Lisäksi teokseen sisältyy liitteenä Aitolahden maanlainsuomennoksen kokonaisteksti. Johdantoluvussa Uusitalo esittelee tutkittavan koodeksin ohella lyhyesti vanhan kirjasuomen lakikielten tutkimushistoriaa, kehitysvaiheita ja tärkeimpiä merkkihenkilöitä. Lisäksi johdantoon sisältyy työn monipuolisen metodologian esittely; työssä hyödynnetään niin kodikologista tutkimusta, forensista lingvistiikkaa kuin käännöstutkimusta. Toisessa luvussa Uusitalo esittelee tutkimustavoitteensa: 1) Aitolahden koodeksin ajoitus kodikologian ja materiaalisen filologian menetelmin, 2) koodeksin intertekstuaalisuuden selvittäminen suhteessa Martinuksen ja Ljungon teksteihin, 3) tekijäntunnistus erityisesti suhteessa Rapolaan (1965), jonka mukaan tekijä olisi Hartvig Speitz, ja 4) koodeksin kielen vertailu vuoden 1642 Biblian kieleen. Näitä aiheita käsitellään luvuissa 3-6. Lopussa on hyvin lyhyt (kahden sivun) yhteenvetoluku. 


\section{Aitolahden koodeksin monipuolinen käsittely}

Väitöskirjansa kolmannessa luvussa Uusitalo selvittää Aitolahden koodeksin taustaa materiaalis-filologisen tutkimuksen ja käsikirjoituksen (käsialan, marginaalimerkintöjen, kopiointivirheiden ym.) tutkimuksen avulla. Vesileimatutkimus viittaa siihen, että koodeksin vanhin mahdollinen ajoitus on 1633 (s. 53). Itse koodeksissa esiintyy vuosiluku 1642, mikä tarkoittaa, että ainakin myöhäisimmät koodeksin osat ovat peräisin tämän vuoden jälkeiseltä ajalta. Koodeksi on suurimmalta osin kirjoitettu samalla käsialalla, mutta pääkäsialan ohessa tekstissä esiintyy kolmea muuta käsialaa, joista kaksi rajoittuu koodeksin ruotsinkieliseen osaan mutta kolmas esiintyy myös lainsuomennoksessa (s. 62-63). Tämän johdosta Uusitalo pohtii, olisivatko eri kirjoittajat osallistuneet lainsuomennoksen kirjoittamiseen sanelun pohjalta. Toisaalta Uusitalo esittää lainsuomennoksesta kohtia, joissa on todennäköisesti tapahtunut kopiointivirheitä niin sanotun katseen harhautumisen (engl. eyeskip) johdosta: kirjuri on epähuomiossa alkanut kopioida väärää kohtaa tekstiä. Tämä puolestaan viittaa siihen, että kirjoittaja on ollut kopioimassa nimenomaan kirjallista tekstiä. Joka tapauksessa Uusitalo osoittaa uskottavasti, että Aitolahden maanlainsuomennos ei ole omaperäinen Ljungon ja Martinuksen lainsuomennosten yhdistelmä, vaan sellaisen yhdistelmän tai hybridin kopio (s. 83). Tämä seikka on merkittävä Aitolahden lainsuomennoksen tekijäntunnistuksessa; palaan tähän asiaan myöhemmin.

Neljännessä luvussa Uusitalo käsittelee Aitolahden maanlainsuomennoksen suhdetta sen kahteen pääasialliseen lähteeseen: Martinuksen 1580-luvulta peräisin olevaan maanlainsuomennokseen ja Ljungon suomennokseen vuodelta 1602. Kolmas tiedossa oleva maanlainsuomennos, Kollaniuksen vuoden 1648 maan- laki, ei ilmeisesti juurikaan vaikuttanut Aitolahden koodeksin tekstiin (s. 84), mikä ehkä merkitsee, että se on peräisin vuotta 1648 edeltävältä ajalta (s. 55). Karkeasti sanoen on niin, että Aitolahden lainsuomennoksen leipäteksti perustuu suurimmalta osin Ljungon suomennokseen, lukuun ottamatta viimeistä jaksoa, "Varkauden menosta", joka on peräisin Martinuksen suomennoksesta. Sisällysluettelot ovat taas peräisin Martinuksen suomennoksesta, vaikka niihin sisältyvä terminologia on osin korjattu Ljungon tekstin mukaan. Otsikot ovat osin peräisin Ljungon, osin Martinuksen tekstistä. Toisaalta Ljungolta periytyvää tekstiä on toisinaan täydennetty seuraamalla Martinuksen tekstiä (s. 90-93). Aitolahden tekstissä esiintyy lisäksi osia, jotka poikkeavat sekä Martinuksen että Ljungon alkuperäisteksteistä ja jotka voivat viitata omaan käännöstyöhön. Uusitalo kuitenkin korostaa, että myös eri Martinuksen maanlainsuomennoksen käsikirjoitusten välillä on jonkin verran sanastollista vaihtelua, joka ei välttämättä pohjaudu itsenäiseen käännöstyöhön (s. 89-90).

Kiinnostavana yksityiskohtana Uusitalo ottaa esiin sen, että "Varkauden menosta" -jaksoon on kopioitu Martinuksen pahasti harhaanjohtava käännösvirhe: ruotsin termi bodrägt 'pesänkavallus' on suomennettu ilmaisulla paatin siirtäminen (Ljungo käyttää termiä talouden wiettelemys) (s. 97-98). Tämä viittaa siihen, että Aitolahden lainsuomennoksen tekijä ei luultavasti ollut lainoppinut.

Uusitalo mainitsee Aitolahden suomennoksen intertekstuaalisten suhteiden yhteydessä myös Turun palossa vuonna 1827 tuhoutuneen Fredenheimin koodeksin, jota on perinteisesti pidetty Martinuksen tekstin kopiona - siinä esiintyy yllä mainittu käännösvirhe - mutta jota välillä on kutsuttu Ljungon kopioksi, mikä Uusitalon mukaan viittaa siihen, että kyseessä olisi samanlainen hybridikäännös kuin Aitolahden teksti. Freden- 
heimin koodeksin alkuperäinen omistaja on Uusitalon mukaan ollut raamatunkäännöskomitean jäsen Jonas Raumannus (s. 104). Huomioiden sen, että Aitolahden lainsuomennos on ilmeisesti kopio toisesta hybriditekstistä, Uusitalon olisi toivonut tarkastelevan sen mahdollista suhdetta Fredenheimin koodeksin lainsuomennokseen hieman syvemmin. Porthanin kirjeessä (Lagus 1886: 3) siteerataan ainoastaan maanlain ensimmäisen luvun (Kuningan Caari) ensimmäiset lauseet, ja juuri tämä osa puuttuu Aitolahden lainsuomennoksesta (s. 76-77). Fredenheimin lainsuomennoksen kieli muistuttaa kyseisessä kohdassa Martinuksen eikä Ljungon tekstiä; Aitolahden Kuninkaan kaaren teksti taas on pääosin peräisin Ljungolta. Mikäli asiasta ylipäätään voi sanoa jotakin, vaikuttaa siis siltä, että Aitolahden lainsuomennos ja Fredenheimin koodeksin mahdollinen hybriditeksti ovat toisistaan itsenäisiä.

Viidennessä luvussa Uusitalo suhtautuu torjuvasti siihen Rapolan (1965) esittämään mahdollisuuteen, että Aitolahden lainsuomennoksen tekijä olisi ollut Hartvig Speitz. Aitolahden lainsuomennoksen tyypillisimpiä ortografisia piirteitä, esimerkiksi sananloppuisen $n$ :n merkitsemistä kahdella $n:$ llä, ei juurikaan esiinny Speitzin teksteissä. Vastaavasti Speitzille tyypilliset kielelliset piirteet, kuten 'ajattelemista' tarkoittava ajachdella-verbi ja jokainen-sanan $h$ :ton muoto, eivät juuri esiinny Aitolahden lainsuomennoksessa (jossa käytetään muotoja ajatella ja jokahinen). Lisäksi edellä mainittu paatin siirtäminen -käännösvirhe viittaa siihen, että Aitolahden lainsuomennoksen kirjoittaja ei ollut lainoppinut, ja Speitz oli nimenomaan lainlukija (s. 120). Forensiseen lingvistiikkaan nojautuen Uusitalo esittää hieman spekulatiivisesti, että on erittäin epätodennäköistä, että Speitz olisi Aitolahden lainsuomennoksen kirjoittaja.

Tekijäntunnistusta käsiteltäessä olisi ollut syytä ottaa paremmin huomioon se Uusitalon aiemmin mainitsema hypoteesi, jonka mukaan Aitolahden lainsuomennos on kopio toisesta (kadonneesta) hybriditekstistä. Tämän valossa Speitzin ja Aitolahden koodeksin käsialan vertaileminen (s. 115-117) ei olisi kovin merkittävää, jollei haluta esittää, että Speitz olisi ainoastaan ollut tekstin jäljentäjä. Mutta jos voitaisiin sulkea pois se mahdollisuus, että Aitolahden maanlainsuomennos olisi Speitzin työ, kuka olisi sitten sen tekijä? Aitolahden lainsuomennos edustaa hämäläismurretta (s. 117), ja - kuten sanottu - kirjoittaja ei ilmeisesti ollut lainoppinut. Näiden seikkojen pohjalta Uusitalo esittää, että "kirjoittaja on voinut olla esimerkiksi joku hämäläinen kihlakunnankirjuri, joiden työtehtäviin kuului erilaisten tärkeiden tekstimateriaalien jäljentäminen" (s. 119).

Kuudennessa ja viimeisessä analyysiluvussa Uusitalo vertaa Aitolahden lainsuomennoksen kieltä vuoden 1642 Biblian kieleen ortografian, fonologian, morfologian, syntaksin ja lauseopin kannalta. Uusitalo toteaa, että Aitolahden lainsuomennoksen kieli on kaikilla tasoilla epäjohdonmukaisempaa ja horjuvampaa kuin Biblian, mikä voi tarkoittaa sitä, että Aitolahden lainsuomennoksen kirjoittaja ei ehtinyt saada kielellisiä vaikutteita Bibliasta.

\section{Ansiokas ja perinpohjainen väitös- kirja}

Vanhojen lainsuomennosten tutkimus on jäänyt vanhan kirjasuomen kauden uskonnollisen kirjallisuuden tutkimuksen varjoon. Lainsuomennosten kieli onkin köyhempää siinä mielessä, että siinä ei esiinny uskonnollisen kielen tyylillistä tai kieliopillista vaihtelua. Lähes koko vanha maanlaki on esimerkiksi kirjoitettu kolmannessa persoonassa. Toisaalta vanhat lainsuomennokset tarjoavat paljon aineistoa esimerkiksi modaalisten ilmausten tutkimiseen (Elsayed 2000; De 
Smit 2005). Käännöstutkimukseen aineisto sopii hyvin taas siksi, että lähdeja kohdekielen suhde on lainsuomennosten tapauksessa verraten yksinkertainen (Inaba 2000: 111). Uusitalon tutkimus osoittaa toisenkin lainsuomennosten tarjoaman tutkimusmahdollisuuden. Suomen lakikieli oli nimittäin suurimmalta osin painamatonta vuonna 1759 ilmestyneeseen Ruotzin Waldacunnan Laki -suomennokseen asti, mutta sillä oli elävä kopiointitraditio. Martinuksen maanlainsuomennoksen säilyneitä käsikirjoituksia on seitsemän, mutta niitä on varmasti kiertänyt enemmän. Fredenheimin koodeksin teksti voi edustaa Martinuksen suomennoksen kadonnutta kopiota. Ljungon maanlainsuomennoksen käsikirjoituksia taas tunnetaan toistaiseksi vain yksi, mutta Uusitalon tutkimuksen valossa on mahdollista, että Aitolahden lainsuomennoksen esikuvana on ollut Ljungon tekstin kadonnut kopio (s. 92). Aitolahden tekstin hybridiset piirteet osoittavat lainsuomennosten kopiointitradition olleen kompleksinen. Kuten Uusitalo huomauttaa (s. 136), vanhojen lakikäsikirjoitusten digitointi avaisi niitä sellaiseen filologiseen tutkimukseen, jota hänen oma väitöskirjansa edustaa.

Uusitalon väitöskirja on huolellisesti tehty ja korkeatasoinen tutkielma, johon muotitermi monitieteinen ei oikeastaan sovi, vaikka Uusitalo osoittaakin hallitsevansa hyvin materiaalis-filologisia menetelmiä, perinteistä historiallista lingvistiikkaa sekä käännöskielen tutkimusta. Hänen väitöskirjansa pikemminkin edustaa vanhaa, hieman unohduksiin jäänyttä monimetodologista tieteenalaa nimeltä filologia. Lukijaan tekee vaikutuksen Uusitalon varovainen, kriittinen ote - joka johtaa kyllä hyvin kiinnostaviin tutkimustuloksiin sekä selkeä, ytimekäs esitystapa.

Kritiikkiä voi esittää vain vähän. Kuten yllä huomautin, Uusitalon sinänsä vakuuttavan hypoteesin, että Aitolahden lainsuomennos olisi alkuperäisen hybridi- tekstin kopio, olisi voinut huomioida paremmin esimerkiksi tekijäntunnistusta käsittelevässä osassa. Väitöskirjan neljä varsinaista analyysilukua tuntuvat paikoin itsenäisiltä tutkimuksilta, jotka olisi voinut kytkeä toisiinsa hieman vahvemmin. Siitä huolimatta väitöskirja on ansiokas ja perinpohjainen esitys melkein tuntemattomasta vanhan kirjasuomen tekstistä. Uusitalon työ on tieteellinen siinä sanan parhaimmassa merkityksessä, että se avaa monia mahdollisuuksia tulevalle tutkimukselle.

\section{Merlijn De SMit etunimi.de.smit@finska.su.se}

Kirjoittaja on yliopisto-opettaja Tukholman yliopiston Suomen kielen osastolla.

\section{Lähteet}

De Smit, Merlijn 2005: Nesessiivirakenteiden subjektimerkinnästä vanhimpien lainsuomennosten kielessä.

- Sananjalka 47 s. 64-89.

Elsayed, Duha 200o: Modaliteettien ilmaiseminen vanhassa lakisuomessa. - Matti Punttila, Raimo Jussila \& Helena Suni (toim.), Pipliakielestä kirjakieleksi s. 108-114. Helsinki: Kotimaisten kielten tutkimuskeskus.

InABA, Nobufumi 2000: Vanhan kirjasuomen datiivinen genetiivi I. Eräät nykysuomesta kadonneet lausetyypit Kuningas Kristoferin maanlain ensimmäisen suomennoksen valossa. - Anneli Pajunen (toim.), Näkökulmia kielitypologiaan s. 109-152. Suomi 186. Helsinki: Suomalaisen Kirjallisuuden Seura.

Lagus, Wilhelm 1886: Henrik Gabriel Porthans bref till Mathias Calonius 1. Aren 1791-1796. Skrifter utgifna af Svenska Literatursällskapet i Finland 1. Helsingfors: Svenska Literatursällskapet.

Rapola, Mart Ti 1965: Aitolahden löydös. Teoksessa Pelto jää taakse. Esseitä ja impressioita s. 73-82. Porvoo: WSOY. 